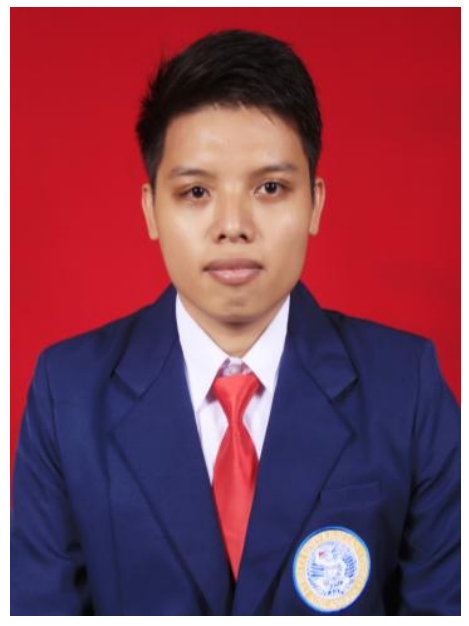

\title{
CHARACTERISTICS OF DEMOCRACY IN ESTABLISHMENT CONSTITUTION
}

Instrument (tool) democracy in the legislation making process that can be implemented are information disclosure, public participation and complaint mechanism. In general instrument (tool) democracy in the legislation making process has been fulfilled but still in a limited scale, in the form of disclosure (information), public participation, and the complaint mechanism. The most dominaty of the instrument (tool) democracy in the legislation making process is Public Participation; Although the public participation are accommodated, but the problem involvement or participation is still more of a procedural nature and the artificial, yet touched on aspects of fundamental and substantial; In the second process of legislation making process, Public Participation are dominated by a particular group mobilization approach is more power and influence than any form of individual consciousness. Using theoretical models of participation of South Africa, then participation in Indonesia over the model called A Model of Public Participation Realism. According to this model, the participation of actors tend to do and dominated by interest groups and particural organizations. Here there is a tendency to understand the «public» in the context of limited on the grounds that the public as a whole may Numbert be involved in the process of legislation making process. Especially in the context of the formation of Horticulture Act, it is clear how participation is only carried out by groups or organizations exist of group interest organization.

Keywords: democracy; constitution; legislation making process; instrument (tool); information disclosure; complaint mechanism; public participation.

Вардана Доді Дюжая, завідувач кафедри права, юридичний факультет, Університет Мухаммад Грешік, Індонезія, Східна Ява, м Рандуаганг

e-mail: dodijayawardana@umg.ac.id \section{Індонезії.}

Характеристика демократичних інструментів реалізації конституційних норм в

У статті розглянуто теоретичні питання реалізації конституційних норм при nідготовці й прийнятті законодавчих актів в Індонезії. Основними інструментами реалізації демократії є відкритий доступ громадськості до інформачії в процесі підготовки й прийняття нормативно-правових актів та надання громадянам можслиості подавати скарги й пропозиції до відповідних органів, які повинні реагувати на них в процесі їх підготовки і прийняття. Однак в цілому по краӥні такі інструменти використовуються все ще не в повній мірі. При цзьому основним фундаментальним інструментом реалізації конституційних норм є гарантування 
доступності інформачії та свободи вираження громадянами своєї думки при підготовці $і$ прийнятті законодавчих актів, яке існує хоча $i$ формально, але як і раніше носить скоріше прочедурний характер. Іншим інструментом є можливість використовувати механізм подачі скарг, щзо певною мірою має мобілізаційний характер, але робить значно більший психологічний вплив на свідомість громадськості, ніж будь-яка інша форма. На основі теоретичної моделі Південно-Африканської Республіки в Індонезї розроблено власну «Модель реалізащії участі громадськості», по якій громадяни об'єднуються переважно в групи і приватні організації за інтересами, які виступають від імені всієї громадськості. Це означає, щуо громадськість в цілому може бути залучена в прочес підготовки та прийняття нормативно-правових актів обмеженою спрямованості, як ие було при підготовцุі Закону про садівництво, коли участь громадськості проявлялося у вигляді пропозицій окремих груп або організацій, щчо мають групову заџікавленість.

Ключові слова: демократія; конституція; розробка законодавства; інструмент; відкритий доступ до інформації; механізм подання скарг; участь громадськості.

\section{Introduction.}

The first amendment of the constitution of the republic of Indonesia, has changed the power of formulating laws, from what was originally held to the President, turned to the authority of the House of Representatives. Structuring the implementation of the legislative function of the House of Representatives, will certainly have an influence on the quality of law formation in Indonesia. Measures toward the formation of a higher quality law, part of an effort to support legal reform, have been realized through a national legislation program. Such improvement efforts involve the formation process (formal), as well as the regulated substance (material). Such a move is expected to provide assurance that the established legislation is able to accommodate rapid needs in the implementation of development.

The law is the legal basis under which all policies that the government will adopt. ${ }^{2}$ The «legal policy» set forth in the law, becomes a means of social accounting, which contains the policy the government seeks to direct people to accept new values. As a form of embodiment of the provisions of Article $22 \mathrm{~A}$ (the result of the second amendment), which states that the procedure for the formation of law, hereinafter regulated by law, has been enacted Law Number 10 of 2004 as has been replaced by

\footnotetext{
${ }^{1}$ Yuliandri, Asas-Asas Pembentukan Peraturan Perundang-Undangan Yang Baik, Gagasan Pembentukan UndangUndang Berkelanjutan, Jakarta: Rajawali Pers, 2011. h. 1.

${ }^{2}$ Siti Sundari Rangkuti, Hukum Lingkungan Dan Kebijaksanaan Lingkungan Nasional (Edisi Ketiga), Surabaya: Airlangga University Press, 2005, h. 12.
} 
Law Number 122011 on the Establishment of Legislation. There are several reasons, which may illustrate the significance of this law:

First, the establishment of legislation is one of the conditions in the framework of the development of national law that can only be realized if supported by the methods and methods that are certain, standard and standards that bind all the institutions authorized to make laws and regulations. Second, to further improve the coordination and smoothness of the legislative process, the Republic of Indonesia as a law-based State needs to have rules on the establishment of legislation. And thirdly, as long as the provisions relating to the establishment of legislation are present in some laws and regulations that are longer in accordance with the law of the Republic of Indonesia. ${ }^{3}$

Furthermore, in view of its substance, Law Number 12 of 2011 Numbert only regulates the procedure (formal process) of the formulation of the law, as stipulated in Article 22 A of the 1945 Constitution, but also on the rules of formulation of legislation, as the juridical foundation in making legislation, both at the central and regional levels. In addition, the law also regulates the system, principles, types and content of legislation, preparation, discussion and approval, promulgation and dissemination (socialization), and community participation (democracy) in the formation of substitute government law/regulation legislation, government regulations, presidential regulations, and local regulations. 4

In relation to the process of law formation, both before and after the amendment of the 1945 Constitution, as well as before and after the enactment of Law Number 10 of 2004 as already amended by Law Number 12 Year 2011 on the Establishment of Laws and Regulations, the reality is still faced with various problems, either substantially, the technical juridical arrangement, or the implementation and enforcement of the law. The House of Representatives and the President as institutions authorized for the establishment of law, as well as the Regional Representatives Council for the matters

\footnotetext{
${ }^{3}$ This provision is a consideration considering the letters a, b and c of Law Number 12 Year 2011 Concerning the Establishment of Laws and Regulations.

${ }^{4}$ Yuliandri, Op.Cit., h.3

(C) Wardana Dodi Jaya, 2018 
pertaining to regional interests, are still faced with several problems.

In this connection it is important to see whether in this era of reform the state has really put forward the aspect of public participation in the formation of law and legislation in Indonesia, the public participation in the planning and discussion (law making process) is needed. Saifudin states that: Participation is a growing system in modern political systems. ${ }^{5}$ The provision of public space or the presence of community participation is an absolute demand for democratization. ${ }^{6}$

The quality of legislation products is largely determined by the process and mechanism of the preparation and discussion. In the process, the more intense and widespread community participation will result in improved and democratic and accommodative products of legislation to the interests of society. Therefore, it is necessary to have a standard level of public participation, both in terms of intensity, scope, media, and instruments of participation that are regulated comprehensively and in detail in the provisions of legislation on the formation of laws. Jimly Asshiddiqie states that: because people are basically sovereign in a democratic country, it is the people who have the right to determine the state policies which will be binding for all the people. ${ }^{7}$

There is often a draft law approved by the People's Legislative Assembly to become law, then passed and enacted by the President, but is immediately criticized sharply that the law needs to be revised. For example, to illustrate this, Law Number. 23 of 1997 on the Management of the Environment, immediately received a «verdict» of revision, immediately after it was enacted. ${ }^{8}$ Other issues can also be revealed, such as when the implementation of Law Number 22 of 1999 (later replaced by Law Number 32 of 2004 on Regional Government). At the beginning of the enactment of this law immediately reap criticism, because the emergence of juridical problems in its application. Example of the latest problem is Law Number 9 Year 2009 on Education

\footnotetext{
${ }^{5}$ Saifudin, Partisipasi Publik Dalam Pembentukan Peraturan Perundang-Undangan, Yogyakarta:FH UII PRESS, h. 7.

${ }^{6}$ Ibid

${ }^{7}$ Jimly Asshiddiqie, Perih Undang-Undang, Jakarta: Rajawali Pers, 2011. h. 22.

${ }^{8}$ Yuliandri, Op.Cit., h. 7.
} 
Legal Entity (UU BHP) and Act of Social Organization, namely Law Number 17 of 2013 on Social Organization. At the beginning of the enactment of this law also immediately reap criticism, because the emergence of juridical problems in its application.

On another occasion, the president also reap criticism. As a result of his «weak» position in the legislation process, after the constitutional amendment, it seems that at some point the president is reluctant to put his signature on a bill already approved by the House of Representatives. For example there are five laws that are Numbert signed by the president, namely: ${ }^{9}$

1. Law Number 18 of 2003 regarding Advocate Profession.

2. Law Numbre 25 of 2002 on Riau Islands.

3. Law Number 32 of 2002 on Broadcasting.

4. Law Number 17 of 2003 on State Finances.

5. Law Number 21 on the Endorsement of the ILO Convention Number 81 concerning Labor Inspection in Industry and Commerce (ILO Convention Numbre 81 on Labor Inspection in Industry and Commerce).

Although such mechanisms are regulated in the 1945 Constitution, but as a consequence of a joint discussion between the president and the House of Representatives, in a plenary session of the House of Representatives, the president has no reason not to endorse an approved Bill. As a result, the law was forced to be put into the Gazette without the approval or signature of the president, in relation to the president who has no veto rights over the law.

Given the various conditions and legal issues that arise after a law is established and declared effective, it may be necessary to develop an integrated regulatory plan, between various similar laws, as well as with other interrelated legislation.

The various phenomena above illustrate that, the formation of law is not only limited to carry out formal process and based on the principles of the establishment of

\footnotetext{
${ }^{9}$ Mechanism of Discussion of Laws in the New Legislature. http: // www. Retrieved on December 21, 2017.
}

(C) Wardana Dodi Jaya, 2018 
good legislation, but also must consider the existence of public participation in the process of formation of the Act, so the quality of legislation which is formed more democratic and in accordance with the desired.

For this reason the topic of democratic characteristics in the formation of legislation is worthy of study. The study focused on the issue of 1). What form of democratic instrument in the formation of law? 2). Whether in the process of formulating the law has fulfilled the instruments of democracy?

This study is a normative legal study conducted through literature study or library research, using conceptual approach and statute approach. The legal materials used are primary, tertiary, and secondary legal materials.

\section{Discussion.}

\section{A. Democratic Instruments in the Formation of the Act.}

In explaining the instruments of democracy in the formation of laws, a question arises why in the formation of a law must be democratic? The answer of that question is the policy formed by the government together with the Parliament which set forth in the form of legislation governing the life of the community whose validity is general and widespread that the object of the application of the content or substance of the law is the community. Since the enforceability of the law made by the government is generally applicable and widespread and its content or substance regulates the community, it is therefore necessary to involve the participation of the community to participate in the establishment of legislation in the following manner: (1). Information Disclosure; (2). Society participation; (3). Mechanism of Objection.

\section{Information Disclosure.}

Disclosure consists of guarantees of information disclosure, accountability, consensus and also freedom of expression.

\subsection{Guarantees of Information Disclosure.}

Involvement and participation in the legislative process requires access and opportunities that are legally formalized to the public to obtain information about 
everything that happens within the parliament, especially with regard to law-making activities. Availability and access to information and community involvement in the legislation process are two interrelated issues. Decision-making in parliament is basically formally conducted in trials, therefore access to attend sessions (meetings) is an important key to community participation. This means that public hearings are an important part of the effort to create an accountable and transparent parliament. In addition, access to court proceedings, trial treaties and various public information forms the basis for broader parliamentary transparency. Thus, the guarantee of public information disclosure, the granting of access to the court and the willingness to pay attention to public inputs become the minimal preconditions for the involvement of the people in the process of legislation.

The constitution of the Republic Indonesia Article $28 \mathrm{~F}$ provides citizens with constitutional guarantees for public information. Mentioned in the constitution that:

each person shall have the right to communicate and obtain information to develop his or her personal and social environment. They also have the right to search, obtain, possess, and store information using any available channel types. ${ }^{10}$

Human rights guarantee in the constitution of the Republic of Indonesia is a mandate to the Government and the House of Representatives to elaborate it further in various implementing legislation in order to become operative.

Therefore, all information produced and about the administration of the government belongs to the people as a mandate. It is therefore appropriate that information about activities funded with public funds be public information as well. This is the basis for the principle that public information is open and accessible.

Mas Achmad Santosa ${ }^{11}$ states that an open government requires guarantees on five issues, namely: (i) the right to monitor the behavior of public officials in carrying

\footnotetext{
${ }^{10}$ The above description is the sound of the provisions of the Constitution of the Republic of Indonesia Article $28 \mathrm{~F}$.

11 Annotation of Law Number 14 Year 2008 on Transparency of Public Information First Edition of the Central Information Commission of the Republic of Indonesia In cooperation with the Indonesian Center for Environmental Law (ICEL). h. 5. http: // www. Retrieved on December 2017.
} 
out its public role; (ii) the right to obtain information; (iii) the right to engage and participate in the process of public policy formation; (iv) freedom of expression which, among other things, is manifested in the freedom of the press; and (v) the right to object to the rejection of all four prior rights. Guarantee of involvement in the making of the Act is not only given to individuals / groups but also the mass media.

\subsection{Accountability.}

The issue of accountability in the formation of a law is an inseparable requirement to create Good Governance through the product of the law in the context of the administration of the State.

With regard to this accountability, Starling provides the definition of accountability is as follows:

A good synonim for the term accountability is answerability. An organization must be answerable to someone outside itself. When things go wrong, someone must be held responsible. Unfortunately, a frequently heard charge is that government is faceless and that, consequently, affixing blame is difficult. ${ }^{2}$

From the above formulation, starling asserts that accountability is a willingness to answer public questions. ${ }^{13}$ Public questions in the context of accountability imply a liability to various policies and public services. Thus, this accountability is a Condition Sine Quanon for an official ${ }^{14}$ or an office environment ${ }^{15}$ in a democratic State. For, in essence, the power inherent in a position or an office environment in a democratic country is from the people, by the people, to the people and run with the people.

On the basis of the above understanding, it is related to this question of accountability. Jimly Asshiddiqie discloses 7 kinds of accountability concepts of a public office, namely: (1) spiritual accountability, is a form of accountability committed

\footnotetext{
${ }^{12}$ Starling was quoted by Kumorotomo in the accountability of the public bureaucracy: a sketch of the transitional period in saifudin, Ibid., h. 69.

${ }_{13}^{13}$ Ibid.

${ }^{14}$ Officials shl be persons entrusted with the position of the State to act as the duties and functions of the State which shl account for its powers individually, such as the President, Vice President, Minister, Governor, Regent, etc.

${ }^{15}$ The office environment is a work environment consisting of State officials performing the duties and functions of the State and shl be accountable collectively on behf of the institution, for example: the People's Consultative Assembly, the People's Legislative Assembly, the Regional Representative Council and the judiciary.
} 
in the context of one's religious beliefs; (2) ethic accountability, is a form of moral responsibility in performing office duties and public office environment; (3) legal accountability, is a form of accountability viewed from the legal aspect; (4) public accountability, is a form of accountability as a consequence of the existence of a democratic system adopted in a country; (5) financial accountability, is a form of liability related to finance; (6) administrative accountability, is a form of liability relating to administrative technical matters; and (7) professional accountability, is a form of accountability related to professionalism in performing its duties and functions as a state official or state official in the administration of the State. ${ }^{16}$

Furthermore, the establishment of a law is an important step in a State which will place the supremacy of the law with The constitution of the Republic Indonesia as its foundation. Based on this law, there will be various laws and regulations as a further implementer in the administration. The emergence of these laws and regulations shall not be contrary to the law used as the legal basis.

A law occupies a strategic position in governance. The formation of legislation must be accountable to the public in order to create good legislation. The formation of legislation should be done in a transparent, participatory, and accountable manner so that it can be evaluated by the community. The formation of legislation through transparent, participatory and accountable processes is in turn expected to result in laws that are just, obeyed and provide legal certainty. Through the establishment of good legislation, the arrangement of community life, nation and state will lead to the creation of a clean government that is effective government plus Numbern aburies decision-making: governance by rule, accountability, transparency and participation. ${ }^{17}$ Thus, the issue of accountability in the formation of a law is a necessary way to produce an ideal law product.

The holders of legislative powers do have the authority to enact legislation in

\footnotetext{
${ }^{16}$ Jimly Assiddiqie dalam Saifudin, partisipasi publik dalam pembentukan peraturan perundang-undangan. Ibid.

${ }^{17}$ Robert B Seidman, Legislative Drafting For Democratis Social Change dalam Saifudin, h. 71.
} 
accordance with the provisions given by the constitution. thus the legislative power holder basically has the freedom to make the law as he wishes. However, in a democratic State accountability in the formation of this law is very important, given that in the end the people will be affected by the enactment of a law.

\subsection{Consensus.}

In the discussion of consensus or agreement it is related to the existence of «agreement» of the people to carry out the obligations and bear the consequences caused by the relevant legislation. This is because the establishment of legislation should be regarded as a first step towards achieving the goals agreed upon by the government and the people. As suggested by A. Hamid S. Attamimi, the establishment of legislation should be considered as a first step towards achieving goals «mutually agreed upon» by the government and the people. ${ }^{18}$ In such a sense, the consensus should involve the community in the process of preparing and discussing the draft law to be drafted, so that the desired objectives can be achieved. ${ }^{19}$

Furthermore, A. Hamid S. Attamimi also said that, in Indonesia the consensus can be realized with:

«good planning, clear, and open, known to the people about the consequences that will arise and the background and goals to be achieved. It can also be done by spreading the draft laws to the public before its formation. Of course, in addition, if the legislation in question is a law, its deliberations in the House of Representatives can be done by involving as many people as possible through institutions with opinions that we have long had». ${ }^{20}$

\subsection{Freedom of Expression.}

Discussion on freedom of expression, related to public freedom in participating in the process of formulating legislation. The way that can be done in participating is poured in the form of freedom of opinion is through 2 (two) ways that is by formal and

\footnotetext{
${ }^{18}$ A Hamid S Attamimi dalam Saldi Isra, Pergeseran Fungsi Legislasi, Jakarta: Rajawali Pers, 2013. h. 286.

${ }^{19}$ Ibid.

20 A Hamid S Attamimi dalam Yuliandri, Op.Cit., h. 146-147.
} 
formal Numbern. Formal means official means in other words there are certain rules that must be obeyed and not free, whereas formal Numbern is not official generally though there are no rules that are too intriguing, but still there are limits. Then the community can participate in a formal (formal) way through: the delivery of alternative draft laws. While the formal Numbern way is: a). Demonstration (demo). (b) Proposals and inputs through print media; and (c) Proposals and inputs through electronic media. Formal and informal means undertaken by the community to participate above in the process of formulation of the legislation will be described further below:

\section{- Formal Way (official)}

\section{Submission of Alternative Draft Law}

The participation of the community in the form of submission of the Alternative Draft Law can be made by the community by drafting the Alternative Bill when the Draft Law being discussed in the legislative body has not been or is not even aspirational to the interests of the wider community. The drafting of the alternative law is done by following the format as stipulated in the Law of Number 12 Year 2011 on the Establishment of Laws and Regulations. Submission of this Alternative Draft Law should be made in the early stages of the discussion of the Draft Law in the legislative body, ie, simultaneously with the submission of a Draft Law to the House of Representatives by both the Government and the Parliament itself. For, if the submission of the new alternative law is proposed mid or even at the end of the discussion of a Draft Law, then the objective of the proposed alternative Bill will not be effective in influencing the discussion of a Draft Law.

\section{- No Formal Way (Informal)}

Public participation by informal means can be done through: a). Demonstration. (b) Proposals and inputs through print media; and (c) Proposals and inputs through electronic media.

\section{a. Demonstration}

Community participation in the form of demonstration can be done by the 
community in order to support, reject or suppress the material being discussed in the process of forming the law. However, the influence of this demonstration will be more successful in influencing the legislature if it is carried out by the people directly concerned, with a large and continuous number. This demonstration is an expression of the individual's freedom of citizens for their interests which will be regulated in a law. So, this demonstration can not only be regarded as a wind and in the process of forming the law.

\section{b. Proposals And Inputs Through Print Media}

Public participation in the form of suggestions and input through print media can be done by the public by making an opinion on a problem being discussed in the legislative body. This public opinion can be articles, press conferences, interviews, statements, or news headlines from newspapers and magazines. Public participation through the print media is widely done by the community, because the way is relatively practical when compared with other forms of community participation. This means that the perpetrators of community participation will not lose much time to do so.

However, the form of public participation through this print media, has a weak side of the opinion submitted is not necessarily up to the hands of authorities to discuss a Draft Law. Therefore, in addition to submitted to the print media should be sent to the House of Representatives either through the post or email so directly accepted by the completeness of the House of Representatives which was discussing a Draft Law.

\section{c. Proposals And Inputs Through Electronic Media}

Public participation in the form of input through electronic media can be done by the community by creating a dialogue by presenting competent resource persons to a problem being discussed in the legislature. Dialogue through electronic media has a wide range and can encourage people to participate in discussing issues that concern the wider community. Therefore, public participation in the form of electronic media needs to be encouraged in the process of formulating the law so that it will awaken the public about the rights and obligations that will be regulated in the law. 


\section{Public Participation.}

Community participation is defined as the participation of the community, either individually or in groups, actively in the determination of public policy or legislation. ${ }^{21}$ As a concept developed in the modern political system, participation is a space for people to negotiate in the process of policy formulation, especially those that directly impact people's lives. Saifudin states that: Participation is a growing system in modern political systems. ${ }^{22}$ The provision of public space or the presence of community participation is an absolute demand for democratization. ${ }^{23}$ Saldi Isra in his book entitled the shifting function of legislation states that, community participation is defined as the participation of the community, both individually and in groups, actively in the determination of public policy or legislation. ${ }^{24}$

Mas Achmad Santosa further states that participatory public decision making is useful in order that the decisions truly reflect the needs, interests and desires of the wider community. ${ }^{25}$ Associated with the formulation of legislation, while giving space to the public to know early possible the implications of the formulation of legislation, public participation is needed to ensure that the interests of the community are not ignored by legislators.

In connection with Yuliandri's public participation by citing the opinions of Samuel P. Huntington and Joan M. Nelson states that: public participation becomes one of the tools in pouring the values that evolve in society to be poured in a regulation. ${ }^{26}$

Lothar Gundling presents several reasons for the need for public participation in the preparation of a policy, that is: ${ }^{27}$

1. imforming the administration;

2. increasing the readiness of the public to accept decisions;

\footnotetext{
${ }^{21}$ Saldi Isra, Pergeseran Fungsi Legislasi, Op.Cit., h. 282. Dapat juga dibaca pada ulasan mingguan PSHK Desember 2004 minggu kedua, www.parlemen.net, diakses pada tanggal 12 Januari 2014.

${ }^{22}$ Saifudin, Partisipasi Publik Dalam Pembentukan...Op.Cit., h.8.

${ }^{23}$ Ibid.

${ }^{24}$ Saldi Isra, Pergeseran Fungsi Legislasi, Op.Cit, 2013. h. 282.

${ }^{25}$ Mas Achmad Santosa dalam Saldi Isra, Ibid., h 282.

${ }^{26}$ Yuliandri, Op.Cit., h. 187.

${ }^{27}$ Lothar Gundling dalam Yuliandri, Ibid., h. 188.
} 
3. supplementing judicial protection;

4. democratizing decision-making.

Community involvement in the drafting of the Law covered under the meaning of transparency and accountability is that the decision-making process is conducted openly, where the argument of consent or claims on a plan of the Act is conducted in consultation and with the public's knowledge. Furthermore, the existence of community participation has led to a prolonged debate between two opposing and pro-democratic groups with community participation. According to R.B.Gibson, the disagreeing group survives on the basis of elite democracy theory which, while agreeing to community participation, survives on the basis of participatory democracy, ${ }^{28}$

In view of elite democracy theory explains that:

"the scope of democracy is limited to citizens' participation in free and fair elections to fill political positions in government and legislatures. If citizens have exercised their right to vote in free and fair elections, then onward citizens entrust the governance to those elected, while the task of government oversight is done by those elected to the legislature. The democratic elite theory prioritizes the stability and authority of the government. It is the duty of members of the legislature to oversee, that the government in making policy and administrative decisions do not deviate from the public interest of the voters. Limited participation in the view of elite democracy theory is based on the assumption that citizens tend to think themselves (selfish) in order to meet the satisfaction (satisfaction) himself so that in society there are often differences in interests that can cause social disturbance. Therefore, it is the government that has the legitimacy to act on behalf of the community and avoid conflict of demands and instability of the community. ${ }^{29}$

Robert B. Gibson adds that, supporters of the theory of elite democracy survive on the basic assumptions, people tend to think more of themselves so often there are

\footnotetext{
${ }^{28}$ R.B.Gibson dalam Saldi Isra, Op.Cit., h. 283.

${ }^{29}$ Ibid, h. 189.
} 
differences of interests that can lead to conflict. ${ }^{30}$

In contrast to elite democracy, proponents of participatory participatory theory of democracy, judging importance in terms of the existence of community participation, suggesting that:

«The citizens both individually and in groups, are not merely consumer of satisfaction, but require opportunities and encouragement for self-expression and development. According to the followers of the theory of participatory democracy, it is assumed that citizens of each other are always in a state of conflict of interest, but instead view that the essence of the human personality is complementary in collective life so that each other able to harmonize individual interests with the common interest (sosiall interest) through acceptable means. According to followers of the democratic theory of participation, the essence of democracy is to ensure that decisions are made by the government by including citizens who may be affected by those decisions. Therefore, the notion of democracy is to encourage participation in making decisions that affect their lives. Thus, this theory not only wants to bring about democratic governance, but also democratic societies». 31

Bagir Manan put forward several ways community participation can be done with:

1. to include in a team of experts or working groups;

2. conducting public hearings or inviting in meetings;

3. perform valid test to certain parties to get response;

4. undertake workshops before being formally discussed on the board;

5. publish regulations to get public feedback. ${ }^{32}$

Furthermore, according to the theory put forward by Sherry R. Arnstein is the theory of «Ladder Arnstein» which is characteristic of public participation (democracy), in the ladder is loaded with meaning. There are eight steps, symbolizing the eight levels

\footnotetext{
${ }^{30}$ Ibid

${ }^{31}$ Yuliandri, Ibid., h. 189

${ }^{32}$ Bagir Manan, Menyongsong Fajar Otonomi Daerah, Yogyakarta: Pusat Studi Hukum (PSH) Fakultas Hukum UII Yogyakarta, 2004, h. 85
}

(C) Wardana Dodi Jaya, 2018 
of public participation. Arnstein named him, The Ladder of Citizen Participation or popular with The Arnstein's Ladder (Stair Arnstein).

Arnstein classifies the eight steps into three parts in the form of a ladder of participation in that order: ${ }^{33}$

\begin{tabular}{|l|l|l|}
\hline 1 & Citizen Control & \multirow{2}{*}{ Degree of citizen power } \\
\hline 2 & Delegated Power & \\
\hline 3 & Partnership & \multirow{3}{*}{ Degree of tokenism } \\
\hline 4 & Placation & \\
\hline 5 & Consultation & \multirow{2}{*}{ Numbern participation } \\
\hline 6 & Informing & \\
\hline 7 & Therapy & Manipulating
\end{tabular}

The lowest stairs represent non-participation conditions, including: (1) manipulation and (2) therapy. Then followed by stairs (3) informing, (4) consultation, and (5) placation, where the three ladders are described as tokenism levels. Tokenisme can be interpreted as a conscious policy, in the form of superficial efforts or a symbolic action in the achievement of a goal. So simply abort a mere obligation and not a genuine effort to engage society in a meaningful way. The next ladder is (6) partnership, (7) delegated power, and (8) citizen control. The last three ladders illustrate a change in the balance of power that Arnstein considered a real form of community participation. ${ }^{34}$

\section{Mechanism of Objection.}

The discussion on the mechanism of the objection, in relation to the form or steps that can be taken by the public against the objection or dissatisfaction of the public to the presence of a law made by the government together with the People's Legislative Assembly and enacted by the government in the State Gazette. The objection mechanism that can be done by the community is by: (a) a protest against the presence of a new law; and (b) demands for judicial review of the law.

\subsection{Demonstration Against the Presence of the New Law.}

The existence of a new law can be addressed by a variety of people, because it is

\footnotetext{
${ }^{33}$ Menaiki Tangga Arnstein Menata Partisipasi Publik Yang Ideal. http://www. diakses pada tanggal 20 Desember 2017. Baca juga Hendra Karianga, Politik Hukum Dalam Pengelolaan Keuangan Daerah, Jakarta: Prenada, 2013. h. 166.

${ }^{34}$ Ibid. 
very possible with the new law that is not solve the problem, but it creates new social problems in society. That attitude can be either support or rejection of the birth of a new law embodied by the demonstration. Unfortunately, however, the protests against the new law were aimed at a new law rather than supporting the emergence of new legislation. In fact, protests can also be made against the existence of new laws in accordance with the wishes of the community. Therefore, this demonstration is a form of public participation in the process of forming laws, especially protests that refuse because it will encourage refinement or replacement with a better law. ${ }^{35}$

\subsection{Demand of Testing Against the Act.}

A law that has been produced by the legislature and has been ratified by the President and contained in the gazette of the state has binding and valid power applicable in the community. For people who have not or are not satisfied with the birth of a law can make a petition for judicial review of the law.

The existence of a judicial review of the law is intended in order to maintain the constitutional standing of the abuse of power from the legislative organs. For, the law is made by the legislative body which is a political institution and therefore inevitably can be loaded with political interests in it.

Thus, the demand for judicial review of the law is the right of the community to be guaranteed in realizing the participation of the community in the process of forming the law. It is necessary to have institutions that are consistently given the authority to conduct material judicial review of legislation products that are perceived to be detrimental to society, and the idea for this material test basically existed since the formulation of the Constitution of the Republic of Indonesia.

Along with the opening of the tap of democracy and the increasing of public participation in the reform era in regulating the constitution of constitutional life, the petition for judicial review or the judicial review of the law is allegedly contradictory to

\footnotetext{
35 As an example of this rejected demonstration is the rejection of Law No. 25 of 1997 on Manpower rejected by labor because it is not in accordance with the aspirations of labor and subsequently replaced by Act No. 13 of 2003 on Manpower. See also demonstrations of rejection of hazardous state legislation failing to be passed as law by the president.
} 
the Constitution of the Republic of Indonesia's Republic of Indonesia Constitution Court and the examination of laws and regulations under the law, the law is allegedly contrary to the law then its testing by the Supreme Court ${ }^{36}$ experienced a significant increase.

\section{B. Formation of the Act According to Democratic Instruments.}

In the previous explanation it has been explained that the instruments of democracy in the formulation of the law are characterized by the disclosure of information, the participation of the community, and the mechanism of objection. To find out in this study the authors will review 2 (two) laws as an example that the two laws have met the instruments of democracy. The laws that will be the author of review in this study is law number 44 of 2008 on Pornography and Act Number 13 of 2010 on Horticulture. The reason the authors review the two laws in this study, because the process of formation of the law is a lot of controversy in the sense that there is a pro and there is a counter to the legislation in the two laws in the community.

1. Information Disclosure, Community Participation and Objection Mechanism in the Establishment of Law Number 44 Year 2008 on Pornography.

In the process of formulating Law Number 44 Year 2008 on Pornography there are various elements of society both individually and in groups who convey their aspirations to influence the process of public policy making in representative institutions. The attitude of this society can be support, rejection and input to a Draft Law. Community support is an attitude agreed with the steps taken by political parties in fighting for their aspirations in a law. The rejection of society is a disagreement toward the existence of a law because it is not in accordance with the aspirations that it wants. Meanwhile, community input is a variety of ideas contributed in order to improve and perfect a Draft Law.

\footnotetext{
${ }^{36}$ The above provision is the sound of Article 9 of Law No. 12 of 2011 on the Establishment of Legislation.
} 


\section{Table 1: Participants Category of Institutions / Social Organizations ${ }^{37}$}

\begin{tabular}{|c|l|l|}
\hline Number & \multicolumn{1}{|c|}{ Group } & \multicolumn{1}{|c|}{ Community Organization } \\
\hline 1 & Religion & $\begin{array}{l}\text { Indonesian Ulema Council, Church Fellowship } \\
\text { Indonesia, Walubi Conference, and the Islamic } \\
\text { Defenders Front }\end{array}$ \\
\hline 2 & $\begin{array}{l}\text { Womens } \\
\text { Organizations }\end{array}$ & $\begin{array}{l}\text { Head of Muslimat Center, Nasyiatul Aisyiah, } \\
\text { Nahdlatul Ulama (NU), Muslim Women and Mualim }\end{array}$ \\
\hline 3 & Profession & $\begin{array}{l}\text { Association of Indonesian Film Artists, Association of } \\
\text { Private Television Companies Indonesia and Malay } \\
\text { Artist Association of Indonesia }\end{array}$ \\
\hline 4 & Institution & $\begin{array}{l}\text { Indonesian Broadcasting Commission and Union of } \\
\text { Journalists Indonesia }\end{array}$ \\
\hline
\end{tabular}

\section{Table 2: Individual Category Participants ${ }^{38}$}

\begin{tabular}{|c|l|l|l|}
\hline Number & Name of Artist & Number & Name of artist \\
\hline 1 & Titik Puspa & 11 & Darwis Triadi \\
\hline 2 & Anwar Fuadi & 12 & Dappi Lingga \\
\hline 3 & Anjasmara & 13 & Meggy Z \\
\hline 4 & Inul Daratista & 14 & Faizal Dath \\
\hline 5 & Annisa Bahar & 15 & Cici Paramida \\
\hline 6 & Ira Swara & 16 & Jaja Mihardja \\
\hline 7 & Uut permatasari & 17 & Hetty Sundjaya \\
\hline 8 & Dewi Perssik & 18 & Mansyur S \\
\hline 9 & Sarah Azhari & 19 & Siti KDI \\
\hline 10 & Fitriah Alvy & 20 & Venty Numberor \\
\hline
\end{tabular}

Outside of the Public Hearings forum on the special committee of the House of People's Representatives, there are also various community actions (mechanisms of objection marked by demonstrations) which are broadly divided into two, namely those supporting the establishment of the Pornography Act and those opposed or denied the establishment of the Pornography Act. In terms of groups that support the Pornography Act, there are at least 4 actions, namely: 1). The Action of Million People; 2). Support from 12 organizations; 3). Surabaya Women's Coalition Support the Pornography Act;

\footnotetext{
${ }^{37}$ Minutes of the Draft Law on Pornography and Fornoaction

${ }^{38}$ Minutes of the Draft Law on Pornography and Fornoaction

(C) Wardana Dodi Jaya, 2018 
4). Indonesian Ulema Council. ${ }^{39}$ Meanwhile, from the refuse camp, there are at least 4 major actions, namely: 1). Events of the Thousand Tayub title; 2). Cultural Carnival; 3). Society of Unity in Diversity; and 4). pancasila our home. ${ }^{40}$

\subsection{Disclosure of Information, Community Participation and Mechanism of} Objection in the Establishment of Law Number 13 Year 2010 on Horticulture

Table 15: Parties of Participants and Stages of Horticulture Law Establishment. $^{41}$

\begin{tabular}{|c|c|c|}
\hline $\begin{array}{c}\text { Parties of } \\
\text { Participants }\end{array}$ & Stages & $\begin{array}{c}\text { Forms And Instruments } \\
\text { Participation }\end{array}$ \\
\hline $\begin{array}{l}\text { Academics, Higher } \\
\text { Education, Local } \\
\text { Government, and } \\
\text { Observer / Expert }\end{array}$ & $\begin{array}{l}\text { Legal Development Plan, } \\
\text { The national legislation program, } \\
\text { classification and harmonization, } \\
\text { synchronization and socialization, } \\
\text { preparation of manuscripts, } \\
\text { Stipulation } \\
\text { and Dissemination, Preparation and } \\
\text { Preparation of Academic Paper, } \\
\text { Formulation } \\
\text { Draft Laws and Harmonies, } \\
\text { Rounding and Stabilization of } \\
\text { Design Conceptions }\end{array}$ & $\begin{array}{l}\text { Lobby, Proposed Draft of Law } \\
\text { and Media Opinion. }\end{array}$ \\
\hline $\begin{array}{l}\text { Association } \\
\text { Citizens } \\
\text { Academics, Higher } \\
\text { Education } \\
\text { Local government } \\
\text { Foundation, Non } \\
\text { Governmental } \\
\text { Organization, } \\
\text { Observer / Expert }\end{array}$ & $\begin{array}{l}\text { Level } 1 \text { discussion through } \\
\text { Commission Meetings, Joint } \\
\text { Meetings Commission Meeting of } \\
\text { Legislation Body, Budget Agency } \\
\text { Meeting, Then proceed with Level II } \\
\text { Talks, namely the Plenary Session } \\
\text { of the House of Representatives. }\end{array}$ & $\begin{array}{l}\text { Material proposal, Publi } \\
\text { Hearing Meeting, Receiving } \\
\text { Visits } \\
\text { Work, and Media Opinion }\end{array}$ \\
\hline $\begin{array}{l}\text { Government } \\
\text { (President } \\
\text { Minister) } \\
\text { Observer/Expert } \\
\text { Foundation/Non } \\
\text { Governmental } \\
\text { Organization. }\end{array}$ & $\begin{array}{l}\text { Phase of Legaliza } \\
\text { Promulgation }\end{array}$ & $\begin{array}{l}\text { Government Coordination, } \\
\text { Dissemination, Socialization } \\
\text { with stakeholders }\end{array}$ \\
\hline
\end{tabular}

\footnotetext{
${ }^{39}$ Action groups that support the Pornography Act, http: // www. Retrieved on December 21, 2017

${ }^{40}$ Rejection Action Against the Attendance of Pornography Act, http: // www. Retrieved on 21December 2017

${ }^{41}$ Minutes of the Horticulture Act Draft, Secretary General of the House of Representatives.
} 
From the table above can be explained that the process of forming Horticulture Act at least through four stages, starting from the planning process of Prolegnas, Preparation of Academic Paper Draft and Draft of the Draft Law, Discussion (Level 1 Discussion), and Pengesehan (decision making / level II). The relatively quiet discussion of the Horticultural Draft Law from the public controversy stance helped to discuss it more briefly. The groups involved in the stages of the legislative process are also not very diverse except only the stakeholders who received the official invitation from the House of Representatives.

The relatively harsh protest against the presence of the Horticultural Draft Law came only from the Forum for the Environment and the Agrarian Reform Consortium which considered the Bill to be aligned and only meet the interests of large-scale enterprises. They highlight several articles that accommodate the core system of plasma and subcontracted farmers. ${ }^{42}$

\section{Conclusion.}

Based on the results of research and analysis conducted through the assessment as described in the previous chapters, to the following conclusions:

a. That the form of instruments (tools) of democracy in the formation of legislation that can be realized in the form of guarantee of information disclosure, public participation and mechanism of objections. Where Information Disclosure can be: (a). Information disclosure guarantee, (b). Accountability, (c). Consesnsus (deal). Community Participation, The objection mechanism can be: (a). Demonstration against the coming of new law, and (b). Demand testing against legislation. And Most of the instruments (tools) of democracy in the formulation of legislation is the most dominate (fulfilled) is the community participation.

b. Whereas in the Formation of Act According to Democracy Instrument in the form of guarantee of information disclosure, public participation, and mechanism of

\footnotetext{
${ }^{42}$ Community Participation in the Formation Process of Law in the House Post Amendment Undanga-Undang Republik republic Indonesia. http: // www. accessed on December 20, 2017.
} 
objection generally have been implemented although still in a limited scale. In both legislative process, Law Number 44 Year 2008 About Pornography and Law Number 13 Year 2010 About Horticulture, the participants of participation are more dominated by certain groups who use the mobilization approach of strength and influence rather than the form of individual consciousness.

\section{Daftar Pustaka}

\section{Buku}

Asshiddiqie, Jimly. 2011. Perihal Undang-Undang. Jakarta: PT Raja Grapindo Persada.

Astawa, I Gde Pantja dan Suprin Na'a. 2008. Dinamika Hukum Dan Ilmu PerundangUndangan Di Indonesia.Bandung: PT ALUMNI.

Halim, Hamzah dan Kemal Redindo Syahrul Putera. 2013. Cara Praktis Menyusun Dan Merancang Peraturan Daerah Suatu Kajian Teoritis Dan Praktis Disertai Manual Konsepsi Teoritis Menuju Artikulasi Empiris, Jakarta: Katalog Dalam Terbitan.

Isra, Saldi. 2013. Pergeseran Fungsi Legislasi. Jakarta: Rajawali Pers.

Manan, Bagir. 2004. Menyongsong Fajar OtoNumbermi Daerah, Yogyakarta:Pusat Studi Hukum (PSH) Fakultas Hukum UII Yogyakarta.

Rangkuti, Siti Sundari. 2005. Hukum Lingkungan Dan Kebijaksanaan Lingkungan Nasional.Surabaya: Airlangga University Press.

Saifudin. 2009. Partisipasi Publik Dalam Pembentukan Peraturan Perundang-Undangan. Yogyakarta:FH UII PRESS.

Yuliandri. 2011. Asas-Asas Pembentukan Peraturan Perundang-Undangan Yang Baik, Gagasan Pembentukan Undang-Undang Berkelanjutan. Jakarta: Rajawali Pers.

\section{Website}

http://www. Menaiki Tangga Arnstein Menata Partisipasi Publik Yang Ideal. Diakses pada tanggal 17 Desember 2017.

http://www. Mekanisme Pembahasan Undang-Undang Dilegislatif Baru. Diakses pada tanggal 17 Desember 2017.

http://www. Anotasi Undang-Undang Number 14 Tahun 2008 Tentang Keterbukaan Informasi Publik, Edisi Pertama Komisi Informasi Pusat Republik Indonesia Bekerjasama dengan Indonesian Center for Environmental Law (ICEL). Diakses pada tanggal 3 Maret 2014. Mengkaji kebijakan tentang akses dan Informasi serta partisipasi publik dalam Proses legislasi.

http://www. Aksi kelompok yang mendukung Undang-Undang Pornografi. Diakses pada tanggal 18 Desember 2017.

http://www. Aksi Penolakan Terhadap Kehadiran Undang-Undang Pornografi. Diakses pada tanggal 17 Desember 2017.

http://www. Partisipasi Masyarakat Dalam Proses Pembentukan Undang-Undang Di DPR Pasca Amandmen UUD 1945, diakses pada tanggal 18 Desember 2017.

Risalah Rancangan Undang-Undang Hortikultura, Sekretaris jendral Dewan Perwakilan Rakyat, 2017.

Risalah Undang-Undang Number 44 Tahun 2008 tentang Pornografi.

Risalah Resmi, Kamis, 30 Oktober 2008, Pembicaraan Tingkat II/Pengambilan Keputusan Terhadap Rancangan Undang-undang Pornografi. 


\section{Daftar Peraturan Perundang-Undangan}

Undang-Undang Dasar Negara Republik Indonesia Tahun 1945.

Undang-Undang Republik Indonesia Number 44 tahun 2008 Tentang Pornografi (Lembaran Negara Republik Indonesia Tahun 2008 Number 181, Tambahan Lembaran Negara Republik Indonesia Number 4928).

Undang-Undang Republik Indonesia Number 13 tahun 2010 Tentang Hortikultura (Lembaran Negara Republik Indonesia Tahun 2010 Number 132, Tambahan Lembaran Negara Republik Indonesia Number 5170).

Undang-Undang Number 12 Tahun 2011 Tentang Pembentukan Peraturan Perundang-undangan (Lembaran Negara Republik Indonesia Number 82 Tahun 2011, Tambahan Lembaran Negara Republik Indonesia Number 5234).

Вардана Доди Дюкая, заведуюший кафедрой права, юридический факультет, Университет Мухаммадии Грешик, Индонезия, Восточная Ява, г. Рандуаганг

e-mail: dodijayawardana@umg.ac.id

Характеристика демократических инструментов реализации конституционных норм в Индонезии.

В статье рассмотрены теоретические вопросы реализации конституционных норм при подготовке и принятии законодательных актов в Индонезии. Основными инструментами реализации демократии определень открытый доступ общественности к информации в прочессе подготовки и принятия нормативно-правовых актов и предоставление гражданам возможности подавать жалобы и предложения в соответствующие органы, которые должны реагировать на них в прочессе подготовки и принятия этих актов. Основным инструментом реализации конституцчионных норм является гарантирование доступности информации $u$ свободы выражения гражданами своего мнения при подготовке и принятии законодательных актов, которое существует хотя и формально, но по-прежнему носит процедурный характер. Другим инструментом является возможность использовать механизм подачи жалоб, что в определенной степени имеет мобилизационный характер, но оказывает значительно большее психологическое воздействие на сознание общественности, чем любая другая форма. На основе теоретической модели Южно-Африканской Республики в Индонезии разработано собственную «Модель реализачии участия общественности», по которой граждане объединяются преимущественно в группы и приватные организации по интересам, которые выступают от имени всей общественности.

Ключевые слова: демократия; конституция; разработка законодательства; инструмент; открытый доступ к информации; механизм подачи жалоб; участие общественности.

\section{Надійшла до редколегії 25.05.2018р.}

